\title{
PRODUKSI ANTIBIOTIKA OLEH Bacillus subtilis M10 DALAM MEDIA UREA-SORBITOL
}

\author{
Supartono $^{\left.{ }^{*}\right)}$, Nanik Wijayati ${ }^{1)}$, Lina Herlina ${ }^{2)}$, dan Enny Ratnaningsih ${ }^{3)}$ \\ 1) Jurusan Kimia, FMIPA UNNES, Gedung D6, Kampus Sekaran, Gunungpati, Semarang \\ 2) Jurusan Biologi, FMIPA UNNES, Gedung D6, Kampus Sekaran, Gunungpati, Semarang \\ ${ }^{3)}$ Departemen Kimia, FMIPA ITB, Jl. Ganesha No. 10, Bandung \\ ${ }^{*}$ Penulis korespondensi: Tonosupartono54@yahoo.com
}

\begin{abstract}
PRODUCTION OF ANTIBIOTICS BY Bacillus subtilis M10 IN UREA-SORBITOL MEDIUM. Infection diseases still become the main health problems that suffered by people in Indonesia. Besides, there were many pathogen bacteria found to be resistant to the some antibiotics. Therefore, the efforts to get a new antibiotic require to be done continuously. A new local strain of Bacillus subtilis BAC4 has been known producing an antibiotic that inhibit Serratia marcescens ATCC 27117 growth. To make efficient the local strain, mutation on Bacillus subtilis BAC4 was done by using acridine orange and a mutant cell of Bacillus subtilis M10 that overproduction for producing antibiotic was obtained. Nevertheless, the production kinetics of antibiotic by this mutant has not been reported. The objective of this research was to study the production kinetics of antibiotic by Bacillus subtilis M10 mutant. The production of antibiotic was conducted using batch fermentation and antibiotic assay was performed with agar absorption method using Serratia marcescens ATCC 27117 as bacteria assay. Research result provided that Bacillus subtilis M10 mutant with overproduction of antibiotic produced an antibiotic since $8^{\text {th }}$ hour's fermentation and optimum of it production was at $14^{\text {th }}$ hours after inoculation.
\end{abstract}

Keywords: antibiotic; bacillus subtilis; kinetics; mutant; production

\begin{abstract}
Abstrak
Penyakit infeksi masih menjadi masalah yang utama diderita oleh masyarakat Indonesia. Di samping itu, banyak bakteri patogen yang ditemukan resisten terhadap beberapa antibiotika. Oleh karena itu, upaya-upaya untuk mendapatkan antibiotika baru perlu dilakukan secara terus-menerus. Suatu galur lokal baru Bacillus subtilis BAC4 teridentifikasi memproduksi senyawa antibiotika yang menghambat pertumbuhan Serratia marcescens ATCC27117. Untuk memberdayakan galur tersebut, terhadap Bacillus subtilis BAC4 dilakukan mutasi dengan larutan akridin oranye dan diperoleh mutan Bacillus subtilis M10 yang memproduksi antibiotika berlebihan. Namun, kinetika produksi antibiotika oleh Bacillus subtilis M10 belum pernah dilaporkan. Penelitian ini bertujuan untuk mempelajari kinetika produksi antibiotika oleh mutan Bacillus subtilis M10. Bacillus subtilis M10 difermentasikan ke dalam media urea-sorbitol dan diamati kemampuan produksi antibiotikanya menggunakan Serratia marcescens ATCC 2711 sebagai bakteri uji. Hasil penelitian menunjukkan bahwa mutan Bacillus subtilis M10 memproduksi antibiotika sejak jam ke 8, dan produksi optimumnya terjadi pada jam ke 14 setelah inokulasi.
\end{abstract}

Kata kunci: antibiotika, bacillus subtilis, kinetika, mutasi, produksi

\section{PENDAHULUAN}

Baru-baru ini banyak kita jumpai di tengahtengah masyarakat berbagai macam jenis penyakit yang disebabkan oleh infeksi, baik infeksi oleh bakteri patogen maupun virus. Permasalahan infeksi memang masih menjadi problema kesehatan masayarakat yang utama di Indonesia. Hal ini disebabkan penggunaan antibiotika sebagai obat penyakit infeksi yang tidak teratur oleh sebagian masyarakat. Di sisi lain, juga banyak bakteri patogen yang ditemukan menjadi resisten terhadap berbagai macam antibiotika. Terutama bakteri-bakteri patogen Gram positif, misalnya Staphylococcus aureus, Streptococcus pneumoniae, dan Enterococcus faecalis (Petersen dkk., 2002, Tsuji dkk., 2003, Griffith dkk., 2003). Beberapa penelitian mengungkapkan bahwa berbagai bakteri patogen dapat memproduksi enzim $\beta$-laktamase yang mampu menghidrolisis cincin $\beta$ - 
laktam, sehingga menonaktifkan penisilin-penisilin (Navarro dkk., 2004). Oleh karena itu, upaya-upaya untuk menemukan antibiotika baru perlu dilakukan secara terus-menerus.

Saat ini, upaya untuk mendapatkan antibiotika baru baik dari tanaman, hewan maupun bakteri menjadi bagian yang menarik bagi kalangan peneliti. Beberapa upaya itu di antaranya telah berhasil dan diproduksi secara besar-besaran, misalnya: basitrasin, suatu antibiotika polipeptida dari beberapa galur Bacillus licheniformis dan Bacillus subtilis telah diproduksi dalam skala industri dan dipasarkan. Suatu galur lokal baru Bacillus sp. BAC4 diketahui memproduksi enzim penisilin $G$ asilase (PGA) ekstrasel (Moeis dkk., 2000; Supartono dkk., 2008b). Galur lokal ini menunjukkan kesamaan yang tinggi dengan Bacillus subtilis (Kusumaningrum, 1999). Seperti halnya genus-genus Bacillus lainnya, galur lokal tersebut juga memproduksi protease ekstrasel. Dari uji mikrobiologis untuk mengetahui potensinya memproduksi PGA, teridentifikasi bahwa Bacillus subtilis BAC4 juga menghasilkan senyawa antibiotika yang menghambat pertumbuhan Serratia marcescens ATCC 27117 suatu bakteri Gram negatif. Hingga saat ini, kondisi produksi dan karakteristik PGA dan protease ekstrasel Bacillus subtilis BAC4 telah diketahui dengan baik (Supartono, 2003). Selanjutnya, terhadap Bacillus subtilis BAC4 telah dilakukan mutasi dengan larutan akridin oranye sebagai upaya memberdayakan galur tersebut dan diperoleh sel mutan Bacillus subtilis M10 yang mampu memproduksi antibiotika secara berlebihan. Namun, kinetika produksi antibiotika oleh mutan Bacillus subtilis M10 sampai saat ini masih belum pernah dilaporkan. Penelitian ini dimaksudkan untuk mempelajari kinetika produksi antibiotika oleh mutan Bacillus subtilis M10 dalam media urea-sorbitol, sehingga diketahui kondisi optimum bagi produksinya. Proses mutasinya dilakukan dengan larutan akridin oranye pada berbagai konsentrasi, kemudian dilakukan seleksi dan karakterisasi kolonikoloni mutan yang berpotensi memproduksi senyawa antibiotika secara berlebihan. Lalu dikaji mengenai pengaruh sorbitol, glukosa, ion $\mathrm{Ca}^{2+}$, dan ion $\mathrm{Fe}^{3+}$ pada produksi senyawa antibiotika oleh mutan yang diperoleh. Asumsi yang digunakan dalam penelitian ini adalah akridin oranye dapat menyebabkan terjadinya mutasi pada gen pengkode antibiotika pada Bacillus subtilis BAC4, sehingga diperoleh kolonikoloni mutan yang berpotensi memproduksi antibiotika secara berlebihan (overproduction). Selanjutnya, kondisi optimum dan kinetika bagi produksi antibiotika oleh mutan Bacillus subtilis M10 dipelajari dalam media urea-sorbitol.

Seperti disinggung di muka bahwa upaya untuk mendapatkan antibiotika baru menjadi bagian yang menarik bagi kalangan para peneliti. Sebagai ilustrasi, berikut ini diberikan beberapa hasil penelitian yang berkenaan dengan antibiotika. Beberapa isomer dari campuran basitrasin A, B, C, D, E, dan F berhasil dipisahkan melalui HPLC (Bell, 1991). Basitrasin adalah suatu antibiotika polipeptida yang aktif melawan pertumbuhan bakteri Gram positif seperti Micrococcus flaveus, Micrococcus luteus, dan S. pyogenes. Pengaruh $\mathrm{pH}$ dan glukosa pada produksi basitrasin oleh Bacillus subtilis C 126 juga telah berhasil diteliti (Azevedo dkk., 1993) dan penggunaan basitrasin sebagai promotor pertumbuhan hewanhewan yang tidak mengganggu kesehatan manusia juga berhasil diteliti (Phillips, 1999). Selanjutnya, produksi kanosamin oleh Bacillus cereus UW 85 juga telah berhasil diteliti. Kanosamin adalah suatu antibiotika derivat dari D-glukosa yang menghambat pertumbuhan berbagai patogen tanaman, baik golongan oomycetes, jamur maupun bakteri (Milner dkk., 1996).

Kemudian, peptida sekropin A dari nyamuk Aedes aegypti yang ternyata mampu menghambat pertumbuhan Micrococcus luteus A 270 suatu bakteri Gram positif dan Escherichia coli SBS 363 suatu bakteri Gram negatif juga berhasil diteliti (Lowenberger dkk., 1999). Aktivitas antibakteri dan antijamur dari vasostatin-1, fragmen terminal-N dari kromogranin A berhasil diteliti juga (Lugardon dkk., 2000). Pengaruh protease lon pada produksi antibiotika pyoluteorin oleh Pseudomonas fluorescens Pf-5 juga berhasil diteliti oleh Whistler dkk., 2000. Selanjutnya, antibiotika dari mutan Bacillus subtilis M 40 yang aktif menghambat pertumbuhan patogenpatogen tanaman seperti Botritys cinerea, Ralstonia solanacearum, dan Erwinia carotovora var berhasil diisolasi dan dimurnikan (Bernal dkk., 2002) dan produksi bacilysosin oleh Bacillus subtilis 168 juga berhasil dipelajari (Tamehiro dkk., 2002). Bacilysosin adalah suatu antibiotika fosfolipid baru yang mampu menghambat pertumbuhan berbagai bakteri dan jamur. Bahkan adanya cluster gen dalam Bacillus subtilis 3610 pengkode antibiotika basilaene yang mampu melawan Streptomyces avermitilis berhasil diidentifikasi (Butcher dkk., 2007).

Penelitian aktivitas likocalkon A yang diisolasi dari akar tanaman Glycyrrhiza inflata telah berhasil dilakukan. Likocalkon A ternyata aktif melawan pertumbuhan bakteri Gram positif khususnya galur dari Bacillus spp. (Tsukiyama dkk., 2002). Ekstrak etanol dari jamur Ramaria flava (Schaeff) berhasil diteliti aktivitas antimikrobanya melawan berbagai bakteri (Gezer dkk., 2006). Hasil penelitian menunjukkan bahwa ekstrak etanol jamur ini mampu melawan galur-galur dari Micrococcus flavus, Micrococcus luteus, dan Yersinia enterocolitica, tetapi ekstrak etanol ini tidak menunjukkan aktivitas antibakteri melawan P. aeruginosa, Escherichia coli, Morganella morganii, dan Proteus vulgaris, bahkan menjadi tidak aktif melawan Candida albicans.

Aktivitas in vitro suatu derivat sefalosporin baru RWJ-54428 berhasil diteliti juga (Swenson and Tenover, 2002; Johnson dkk., 2002). Sefalosporin baru RWJ-54428 adalah antibiotika yang aktif menghambat pertumbuhan bakteri Gram positif yang 
resisten terhadap berbagai obat, seperti Staphylococcus aureus yang resisten metisilin dengan konsentrasi penghambatan minimal $\left(\mathrm{MIC}_{90}\right)$ antara 0,5-2 $\mu \mathrm{g} . \mathrm{mL}^{-1}$ dan Enterococcus faecalis dengan $\mathrm{MIC}_{90}$ kurang dari $2 \mu \mathrm{g} \cdot \mathrm{mL}^{-1}$. Kemudian, aktivitas in vivo derivat sefalosporin baru RWJ-54428 berhasil diteliti dan ternyata aktif melawan bakteri patogen Gram positif, termasuk Staphylococcus aureus yang resisten metisilin dan Streptococcus pneumoniae yang resisten penisilin (Griffith dkk., 2003).

Aktivitas antibakteri dan antioksidan ekstrak heksan, etil asetat, etanol, dan air daun Eclipta prostrata (L) melawan Escherichia coli, Klesiella pneumoniae, Shigella dysenteriae, Salmonella typhi, $P$. aeruginosa, Bacillus subtilis, dan Staphylococcus aureus juga berhasil diteliti. Hasil penelitian menunjukkan bahwa aktivitas antibakteri dan antioksidan teramati pada ekstrak etanol dan etilasetat, sedangkan ekstrak heksan dan air tidak menunjukkan hasil yang signifikan (Karthikumar dkk., 2007). Selanjutnya, aktivitas antibiotika in vivo suatu derivat sefalosporin baru S-3578 yang berspektrum lebar ternyata mampu melawan infeksi-infeksi yang disebabkan oleh Staphylococcus aureus yang resisten metisilin dan sama seperti vankomisin (Tsuji dkk., 2003). Penelitian lain, aktivitas in vitro dan in vivo dari antibiotika 2-(Tiazol-2-iltio)-1- $\beta$ metilkarbapenem ternyata meng-hambat bakteri patogen Gram positif yang resisten berbagai macam obat. Larutan encer derivat 2-(Tiazol-2-iltio)-1- $\beta$ metilkarbapenem dalam agar aktif menghambat pertumbuhan Staphylococcus aureus yang resisten metisilin dan S. epidermidis dengan konsentrasi penghambatan minimal, $\mathrm{MIC}_{90}$, kurang dari $4 \mu \mathrm{g} \cdot \mathrm{mL}^{-1}$. Antibiotika ini juga aktif menghambat galur-galur Streptococcus pneumoniae yang resisten penisilinpenisilin dengan $\mathrm{MIC}_{90}$ antara 0,065 sampai dengan 0,5 $\mu \mathrm{g} \cdot \mathrm{mL}^{-1}$ (Ueda dan Sunagawa, 2003). Aktivitas in vitro dari daptomisin menghambat bakteri patogen Gram-positif yang resisten berbagai obat, seperti Staphylococcus aureus, Enterococcus faecium, dan Streptococcus pneumoniae dengan $\mathrm{MIC}_{90} 0,25 \mu \mathrm{g} . \mathrm{mL}^{-}$ 1 juga berhasil diteliti (Critchley dkk., 2003). Akhirnya konsentrasi vankomisin dalam berbagai cairan biologis dan farmasi juga berhasil ditentukan (Vila dkk., 2007). Vankomisin merupakan suatu antibiotika glikopeptida yang sangat efisien melawan sejumlah mikroorganisme Gram positif termasuk Staphylococcus aureus dan S. epidermidis. Sekarang ini resistensi Staphylococcus aureus terhadap vankomisin menjadi perhatian serius bagi para peneliti.

\section{METODE PENELITIAN}

Peralatan yang digunakan dalam penelitian adalah Laminar flow (model BBF6), UV-Vis spektrofotometer (Shimadzu, UV-120-02), autoklaf (GFL), inkubator (Water-Jacketed incubator cell culture), shaker (CMC-4013), mikropipet 50 sampai dengan $1000 \mu \mathrm{L}$ (Eppendorf), sentrifuga (Centurion-
05), neraca listrik (electronic digital-Mettler), $\mathrm{pH}-$ meter (Orion-40), tabung reaksi, cawan patri, erlenmeyer, gelas kimia, dan beberapa peralatan gelas penting lain.

Bahan-bahan yang diperlukan di antaranya adalah akridin oranye, bakto pepton, ekstrak ragi, glukosa, sorbitol, kalsium klorida dihidrat, feri klorida heksahidrat, bakto agar, ekstrak ragi, natrium klorida, urea, aluminium foil, kapas, dan alkohol. Semua bahan kimia yang digunakan dalam penelitian ini baik sebagai komponen media, pereaksi, pelarut maupun komponen lain memiliki kemurnian berderajad pro analisa dari Merck, Sigma, BDH, dan Fluka.

Biakan Bacillus subtilis BAC4 dan $S$. marcescens ATCC 27117 diperoleh dari laboratorium mikrobiologi ITB Bandung.

Secara umum, penelitian ini bertujuan untuk memproduksi senyawa antibiotika oleh Bacillus subtilis BAC4 galur lokal baru, memurnikan dan mengkarakterisasi senyawa antibiotika tersebut. Untuk mencapai tujuan ini, pendekatan yang digunakan adalah:

\section{Penginduksian, Pemilihan, dan Karakterisasi Koloni Bacillus subtilis BAC4 yang Terinduksi}

Penginduksian dilakukan dengan larutan akridin oranye 1 g. $\mathrm{L}^{-1}$, sehingga diperoleh koloni mutan Bacillus subtilis BAC4 yang berpotensi overproduction bagi senyawa-senyawa antibiotika. Karena akridin oranye bersifat mutagenik, maka koloni Bacillus subtilis BAC4 yang berpotensi overproduction itu disebut mutan. Pemilihan mutan yang memproduksi antibiotika berlebihan (overproduction) dilakukan secara mikrobiologis dengan metode Meevootisom dkk., (1983) menggunakan bakteri uji S. marcescens ATCC 27117 (Chong dan Lee, 1978; Kim dkk., 1995), dan Bacillus subtilis BAC4 wild type sebagai kontrol. Selanjutnya, mutan yang diperoleh dikarakterisasi secara mikrobiologis baik morfologi maupun sifat-sifat biokimianya.

\section{Pemilihan Media Biakan dan Penentuan Pertumbuhan Bakteri Mutan}

Dalam hal ini, pengaruh glukosa, sorbitol, ion $\mathrm{Ca}^{2+}$, dan $\mathrm{Fe}^{3+}$ pada produksi senyawa antibiotika oleh galur mutan diteliti. Media biakan cair yang diteliti ada dua jenis, yaitu: media I setiap liternya memiliki komposisi sebagai: glukosa $10 \mathrm{~g}$, urea $1 \mathrm{~g}$, pepton 10 $\mathrm{g}$, dengan $\mathrm{pH}$ 7,0 dan media II setiap liternya memiliki komposisi sebagai: sorbitol $10 \mathrm{~g}$, urea $1 \mathrm{~g}$, pepton 10 $\mathrm{g}$, dengan $\mathrm{pH} 7,0$. Media biakan yang paling baik dipilih berdasarkan ukuran zona bening penghambatan dari pertumbuhan S. marcescens ATCC 27117 dalam cawan agar (Meevootisom dkk., 1983). Pengaruh ion $\mathrm{Ca}^{2+}$ dan $\mathrm{Fe}^{3+}$ yang diteliti masing-masing sebagai larutan $\mathrm{CaCl}_{2} \cdot 2 \mathrm{H}_{2} \mathrm{O}$ dan $\mathrm{FeCl}_{3} \cdot 6 \mathrm{H}_{2} \mathrm{O}$ dengan konsentrasi akhir masing-masing 5 g. $\mathrm{L}^{-1}$ pada produksi antibiotika oleh mutan yang diperoleh. Penentuan konsentrasi sel mikroba dilakukan dengan 
turbidimetri, yaitu dengan mengukur turbidannya pada panjang gelombang, $\lambda, 650 \mathrm{~nm}$ dan kurva kalibrasi sel mikroba kering dalam media cairnya.

\section{HASIL DAN PEMBAHASAN}

Pembuatan sel mutan Bacillus subtilis BAC4 dilakukan secara acak, yaitu: dengan menambahkan larutan akridin oranye $1 \mathrm{~g} . \mathrm{L}^{-1}$ pada berbagai volume $(0,10,20,30$, dan $40 \mu \mathrm{L})$ ke dalam $10 \mathrm{~mL}$ biakan Bacillus subtilis BAC4. Biakan ini kemudian diinkubasi di dalam inkubator goyang (shaker) pada suhu kamar $\left(26^{\circ} \mathrm{C}\right)$ selama 24 jam. Proses mutasi Bacillus subtilis BAC4 memberikan hasil seperti ditunjukkan oleh Tabel 1 dan 2 serta Gambar 1.

Tabel 1. Pertumbuhan sel Bacillus subtilis BAC4 setelah proses mutasi

\begin{tabular}{ccccc}
\hline $\begin{array}{c}\text { Volume } \\
\text { larutan } \\
\text { akridin } \\
(\mu \mathrm{L})\end{array}$ & \multicolumn{2}{c}{$\mathrm{A}(\lambda 650 \mathrm{~nm})$} & $\mathrm{A}$ & $\begin{array}{c}\text { Konsentrasi } \\
\text { Sel }\left(\mathrm{g} . \mathrm{L}^{-1}\right)\end{array}$ \\
\hline 0 (kontrol) & 0,637 & 0,637 & 0,637 & 7,82 \\
10 & 0,835 & 0,835 & 0,835 & 10,25 \\
20 & 0,932 & 0,936 & 0,934 & 11,46 \\
30 & 0,404 & 0,407 & 0,406 & 4,98 \\
40 & 0,422 & 0,424 & 0,423 & 5,19 \\
\hline
\end{tabular}

Tabel 1 menunjukkan bahwa penambahan akridin oranye pada biakan sel Bacillus subtilis BAC4 tidak mengganggu pertumbuhan sel secara signifikan. Pada penambahan 10 dan $20 \mu \mathrm{L}$ larutan akridin oranye $1 \mathrm{~g} . \mathrm{L}^{-1}$ memicu pertumbuhan sel, namun pada penambahan 30 dan $40 \mu \mathrm{L}$ larutan akridin oranye 1 g. $\mathrm{L}^{-1}$ menghambat pertumbuhan sel Bacillus subtilis.

Tabel 2. Diameter zona bening pada penghambatan pertumbuhan S. marcescens ATCC 27117 oleh sel mutan Bacillus subtilis BAC4

\begin{tabular}{ccccc}
\hline $\begin{array}{c}\text { Volume } \\
\text { larutan } \\
\text { akridin }(\mu \mathrm{L})\end{array}$ & \multicolumn{3}{c}{$\begin{array}{c}\text { Diameter zona bening } \\
(\mathrm{mm})\end{array}$} & Keterangan \\
\cline { 2 - 4 } 0 (kontrol) & 41 & 31 & 36 & \\
10 & 55 & 40 & 47,5 & Mutan M10 \\
20 & 33 & 35 & 39 & \\
30 & 31 & 34 & 32,5 & \\
40 & 27 & 32 & 29,5 & \\
\hline
\end{tabular}

Tabel 2 menunjukkan diameter zona bening pada pengujian produksi antibiotika oleh sel mutan yang diperoleh. Hasil mutasi menunjukkan bahwa pada penambahan $10 \mu \mathrm{L}$ larutan akridin oranye 1 g.L. $\mathrm{L}^{-1}$, memberikan koloni Bacillus subtilis mutan yang mampu menghambat pertumbuhan sel S. marcescens ATCC 27117 paling kuat. Hal ini dibuktikan oleh diameter zona bening yang paling lebar, yaitu rata-rata 47,5 mm. Sel mutan pada kondisi ini diberi tanda sebagai Bacillus subtilis M10.

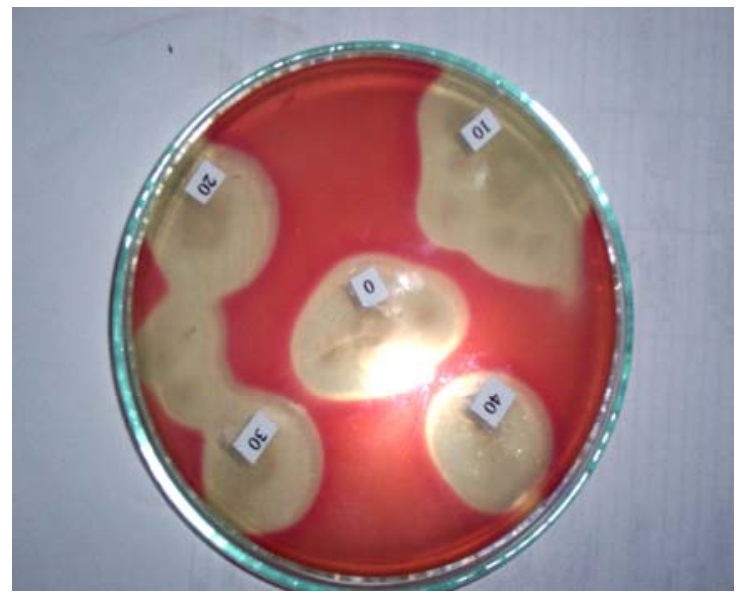

Gambar 1. Hasil pengujian produksi antibiotika oleh sel mutan Bacillus subtilis BAC4 dengan larutan akridin oranye 1 g.L. ${ }^{-1}$ pada berbagai konsentrasi ( 0 : tanpa larutan akridin oranye, 10: dengan $10 \mu \mathrm{L}, 20$ : dengan $20 \mu \mathrm{L}, 30$ : dengan 30 $\mu \mathrm{L}, 40$ : dengan $40 \mu \mathrm{L}$ larutan akridin oranye).

Gambar 1 memperlihatkan hasil pengujian produksi antibiotika secara mikrobiologis oleh sel mutan yang diperoleh dengan bakteri uji $S$. marcescens ATCC 27117. Mutasi dengan volume larutan akridin oranye $10 \mu \mathrm{L}$ memberikan koloni Bacillus subtilis yang mampu menghambat pertumbuhan sel S. marcescens ATCC 27117 paling kuat. Selanjutnya, sel mutan yang diperoleh pada kondisi ini disebut sebagai Bacillus subtilis M10 (Supartono dkk., 2008a). Hasil penelitian ini menyerupai hasil penelitian Bernal dkk. (2002), yaitu penggunaan akridin oranye untuk memutasi $B$. subtilis A47 dan memberikan sel mutan Bacillus subtilis M40 yang mampu memproduksi antibiotika berlebihan penghambat pertumbuhan patogen tanaman $B$. cinerea, $R$. solanacearum, dan E. carotovora.

Proses mutasi ini terjadi karena zat warna akridin oranye yang merupakan senyawa aromatis berinterkalasi ke dalam pasangan basa-basa molekul DNA dan dapat menyebabkan terjadinya penyisipan atau penghapusan basa-basa nukleotida selama proses replikasi (Bernal dkk., 2002). Hasilnya dapat berupa pembentukan suatu protein yang cacat atau tidak terjadi pembentukan protein sama sekali (Crueger dan Crueger, 1984). Gambar 2 menunjukkan struktur kimia dari akridin oranye yang digunakan sebagai zat mutagenik dalam penelitian ini.<smiles>CN(C)c1ccc2cc3ccc(N(C)C)cc3nc2c1</smiles>

Gambar 2. Sruktur kimia akridin oranye

Kemudian, pengaruh glukosa dan sorbitol sebagai sumber $\mathrm{C}$ dalam produksi antibiotika oleh 
Bacillus subtilis galur mutan (M10) diteliti. Selanjutnya, pengaruh ion $\mathrm{Ca}^{2+}$ dan $\mathrm{Fe}^{3+}$ pada produksi antibiotika oleh galur mutan M10 juga diteliti. Media produksi yang diusulkan adalah: Media I, setiap liternya memiliki komposisi glukosa $10 \mathrm{~g}$, bakto pepton $10 \mathrm{~g}$ dan urea $1 \mathrm{~g}$. Media II, setiap liternya memiliki komposisi sorbitol $10 \mathrm{~g}$, bakto pepton $10 \mathrm{~g}$ dan urea $1 \mathrm{~g}$. Hasil penelitian pengaruh penambahan glukosa dan sorbitol sebagai sumber $\mathrm{C}$ dalam produksi antibiotika dan pemilihan media produksi seperti disajikan pada Tabel 3 dan Gambar 3 berikut ini.

Tabel 3. Pengaruh sumber $\mathrm{C}$ pada diameter zona bening penghambatan pertumbuhan $S$. marcescens oleh sel mutan Bacillus subtilis M10

\begin{tabular}{lcccl}
\hline \multirow{2}{*}{ Jenis media } & \multicolumn{3}{c}{$\begin{array}{c}\text { Diameter zona bening } \\
\text { (mm) }\end{array}$} & \multirow{2}{*}{ Keterangan } \\
\cline { 2 - 4 } & 1 & 2 & Rata-2 & \\
\hline Kontrol & 40 & 40 & 40 & \\
$\begin{array}{l}\text { Media I } \\
\text { glukosa) }\end{array}$ & 43 & 44 & 43,5 & \\
$\begin{array}{l}\text { Media II } \\
\text { (sorbitol) }\end{array}$ & 50 & 53 & 51,5 & Terpilih \\
\hline
\end{tabular}

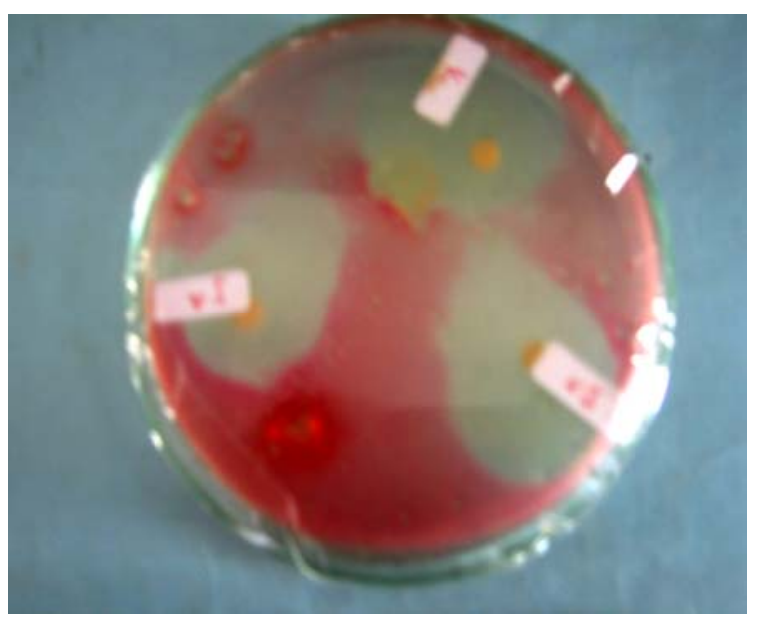

Gambar 3. Hasil pemilihan sumber C media oleh sel mutan Bacillus subtilis M10 [K: kontrol, I: dengan glukosa dan II: dengan sorbitol]

Penelitian mengenai media produksi antibiotika oleh sel mutan Bacillus subtilis M10 memberikan hasil bahwa media II dengan sorbitol sebagai sumber C lebih baik dari pada media I yang menggunakan glukosa sebagai sumber C. Hasil penelitian ini juga mirip dengan hasil penelitian Bernal dkk. (2002) pada produksi antibiotika oleh isolat M40 bahwa adanya glukosa sebagai sumber $\mathrm{C}$ dalam media menghambat bagi produksinya.

Selanjutnya, penelitian mengenai pengaruh ion $\mathrm{Ca}^{2+}$ dan $\mathrm{Fe}^{3+}$ pada produksi antibiotika oleh mutan Bacillus subtilis M10 memberikan hasil seperti disajikan pada Tabel 4 dan Gambar 3 berikut ini.
Tabel 4. Pengaruh $\mathrm{Ca}^{2+}$ dan $\mathrm{Fe}^{3+}$ pada diameter zona bening penghambatan pertumbuhan $S$. marcescens oleh sel Bacillus subtilis mutan M10

\begin{tabular}{cccccc}
\hline \multirow{2}{*}{$\begin{array}{c}\text { Jenis } \\
\text { media }\end{array}$} & \multicolumn{4}{c}{ Lebar zona bening $(\mathrm{mm})$} & \multirow{2}{*}{ Keterangan } \\
\cline { 2 - 5 } & 1 & 2 & 3 & Rata $^{2}$ & \\
\hline Kontrol & 27 & 27 & 28 & 27,3 & \\
$\mathrm{Ca}^{2+}$ & 40 & 43 & 41 & 41,7 & Terpilih \\
$\mathrm{Fe}^{3+}$ & 13 & 8 & 10 & 10,3 & \\
\hline
\end{tabular}

Tabel 4 menjelaskan hasil pengukuran diameter zona bening dari penghambatan pertumbuhan $S$. marcescens ATCC 27117 di mana oleh adanya pengaruh ion $\mathrm{Ca}^{2+}$ memberikan diameter yang paling lebar dibandingkan dengan kontrol maupun pengaruh ion $\mathrm{Fe}^{3+}$. Adanya ion $\mathrm{Fe}^{3+}$ menghambat produksi antibiotika oleh mutan Bacillus subtilis M10. Hasil penelitian menunjukkan bahwa penambahan ion $\mathrm{Ca}^{2+}$ dalam media produksi meningkatkan produksi antibiotika oleh sel mutan Bacillus subtilis M10 sekitar empat kali dari adanya ion $\mathrm{Fe}^{3+}$ dalam media produksi.

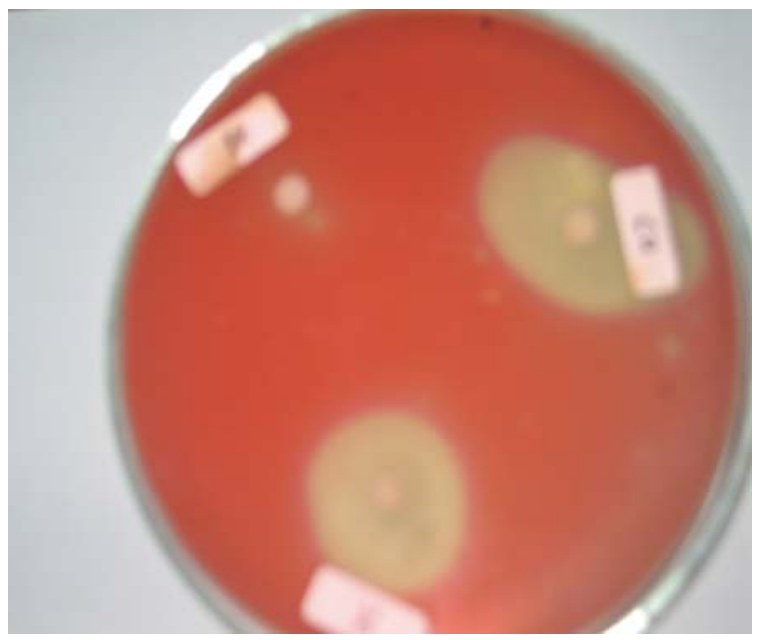

Gambar 3. Pengaruh $\mathrm{Ca}^{2+}$ dan $\mathrm{Fe}^{3+}$ pada produksi antibiotika oleh sel Bacillus subtilis mutan M10 dalam media urea-sorbitol

Gambar 3 menunjukkan bahwa hasil pengujian produksi antibiotika dalam media yang mengandung ion $\mathrm{Ca}^{2+}$ dan $\mathrm{Fe}^{3+}$ secara mikrobiologis. Adanya ion $\mathrm{Ca}^{2+}$ memberikan diameter zona bening yang paling lebar. Jadi hasil penelitian menunjukkan bahwa pengaruh ion $\mathrm{Ca}^{2+}$ adalah meningkatkan produksi antibiotika oleh sel mutan Bacillus subtilis M10 dalam media urea-sorbitol. Sementara itu, adanya ion $\mathrm{Fe}^{3+}$ cenderung menghambat produksi antibiotika tersebut.

Kinetika produksi antibiotika oleh sel mutan Bacillus subtilis M10 dipelajari dengan menggunakan media II yang komposisinya ditambah dengan ion $\mathrm{Ca}^{2+}$ pada konsentrasi akhir 5 g. $\mathrm{L}^{-1}$. Hasil penelitian seperti ditunjukkan oleh Gambar 4 dan 5 berikut ini. 


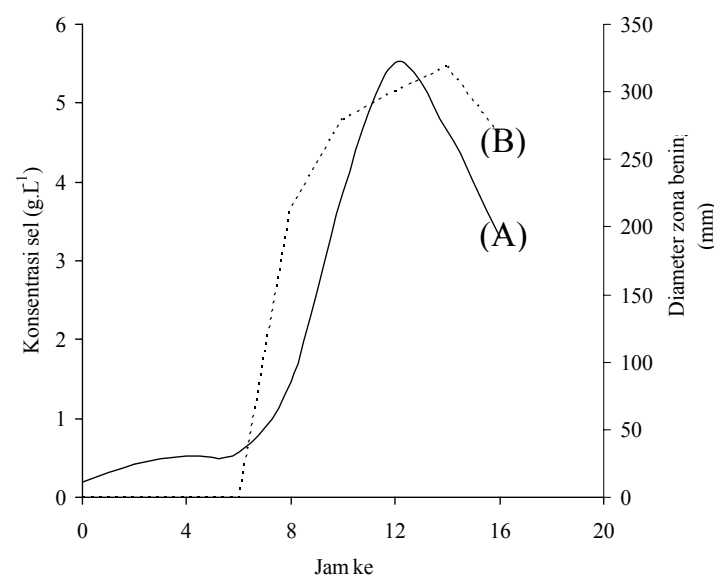

Gambar 4. Kinetika produksi antibiotika oleh sel Bacillus subtilis M10 [(A): Pertumbuhan sel dan (B): Diameter zona bening penghambatan pertumbuhan sel S. marcescens ATCC 27117]

Gambar 4 menunjukkan bahwa pada jam ke 0 sampai dengan jam ke 5 merupakan fase adaptasi. Kemudian, setelah memasuki jam ke 6, sel Bacillus subtilis M10 memasuki pertumbuhan yang sejati dan ketika pertumbuhan selnya memasuki jam ke 12 sel memasuki fase stasioner yaitu suatu fase dengan laju pertumbuhan nol. Selanjutnya, ketika memasuki jam ke 14 sel mutan Bacillus subtilis M10 memasuki fase kematian. Gambar 4 juga menjelaskan bahwa produksi antibiotika oleh mutan Bacillus subtilis M10 dimulai sejak jam ke 8, yaitu ketika pertumbuh sel berada pada fase eksponensial dan mencapai maksimum produksi antibiotikanya ketika sel mutan Bacillus subtilis M10 berada dalam akhir fase stasioner yaitu pada jam ke 14 setelah pertumbuhan selnya memasuki fase kematian (Supartono dkk, 2006).

Gambar 5 menjelaskan hasil uji produksi antibiotika oleh sel mutan Bacillus subtilis M10 secara mikrobiologis. Pengujian tersebut menunjukkan bahwa pada pertumbuhan sel hingga jam ke 6 setelah inokulasi Bacillus subtilis M10 belum memproduksi antibiotika. Produksi antibiotika oleh mutan Bacillus subtilis M10 terdeteksi mulai jam ke 8 ketika pertumbuhan sel menjelang memasuki fase stasioner. Produksi antibiotika oleh Bacillus subtilis M10 ini terus meningkat pada jam ke 10 maupun jam ke 12, dan mencapai maksimum produksinya ketika pertumbuhan selnya memasuki jam ke 14 setelah inokulasi. Produksi antibiotika ini menurun setelah memasuki jam ke 16 yaitu ketika sel mutan Bacillus subtilis M10 itu memasuki fase kematian pertumbuhannya (Supartono dkk., 2006). Hal ini sesuai dengan hakikat dari pada produksi metabolit sekunder oleh suatu mikroorganisme, bahwa produksi metabolit sekunder dimaksudkan untuk mempertahankan keberadaannya dan produksinya dimulai ketika pertumbuhan selnya menjelang memasuki fase stasioner. Antibiotika adalah salah satu bentuk senyawa metabolit sekunder di samping pigmen, alkaloid, dan flavonoid (Brock dan Madigan, 1991).

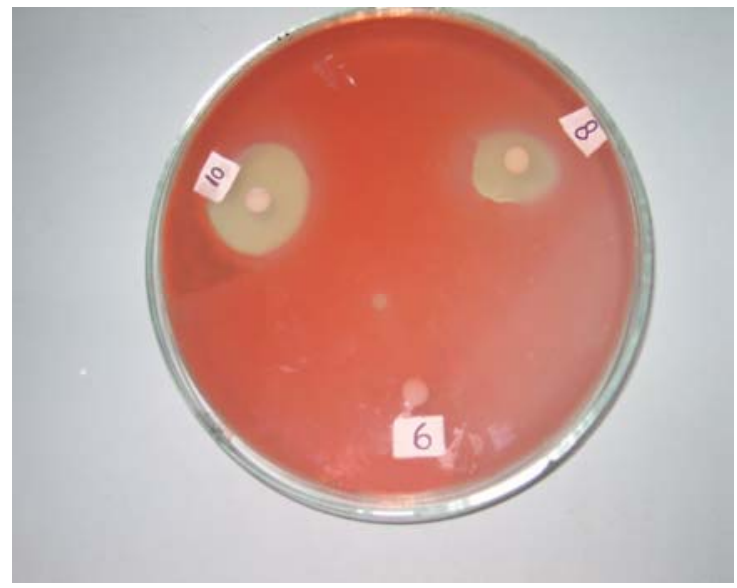

(A)

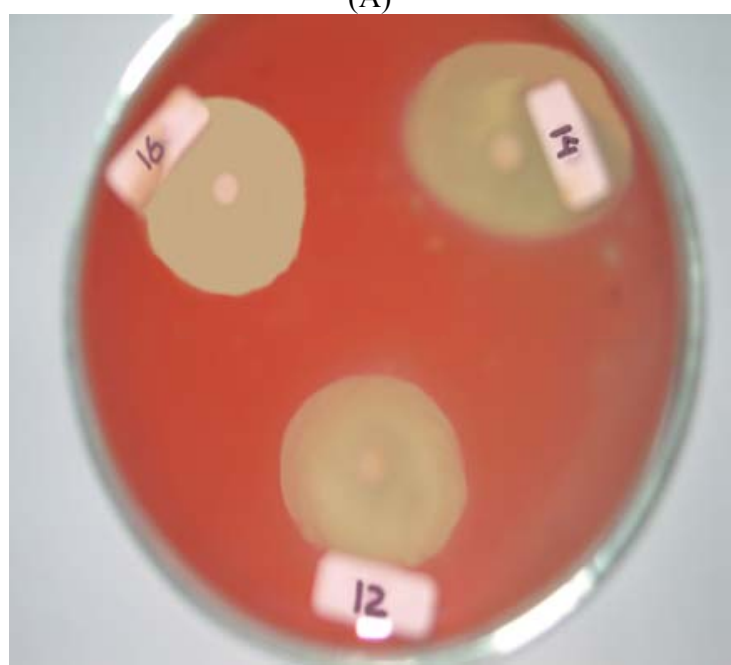

(B)

Gambar 5. Hasil pengujian produksi antibiotika oleh mutan Bacillus subtilis M10 dalam media urea-sorbitol secara mikrobiologis [(A). Pengujian jam ke 0 sampai dengan jam ke 10, (B). Pengujian jam ke 12 sampai dengan jam ke 16.]

Laju pertumbuhan spesifik ditentukan saat pertumbuhan sel pada suatu laju eksponensial. Di bawah kondisi semacam ini, pertumbuhan dijelaskan oleh:

$$
\frac{\mathrm{dX}}{\mathrm{dt}}=\mu . \mathrm{X}
$$

dimana $X$ adalah konsentrasi sel dalam g. $\mathrm{L}^{-1}, t$ adalah waktu inkubasi dalam jam dan $\mu$ melukiskan laju pertumbuhan spesifik dalam jam ${ }^{-1}$.

Pengintegrasian persamaan (1) memberikan persamaan:

$$
\ln \frac{[\mathrm{X}]_{2}}{[\mathrm{X}]_{1}}=\mu \cdot \Delta \mathrm{t}
$$

atau dapat ditulis sebagai:

$$
\ln [\mathrm{X}]_{2}=\ln [\mathrm{X}]_{1}+\mu \cdot \Delta \mathrm{t}
$$

Konsentrasi sel ditentukan dengan cara mengukur kekeruhan atau turbidan cairan fermentasi 
pada $\lambda=650 \mathrm{~nm}$ dan kurva kalibrasi larutan sel kering dalam medianya. Jadi dengan mengalurkan waktu pertumbuhan terhadap ln $[\mathrm{X}]$ dapat diperoleh kurva linier, dan kemiringan kurva (slope) menggambarkan laju pertumbuhan spesifik $(\mu)$, Hasil penelitian memberikan kurva seperti gambar 6 .

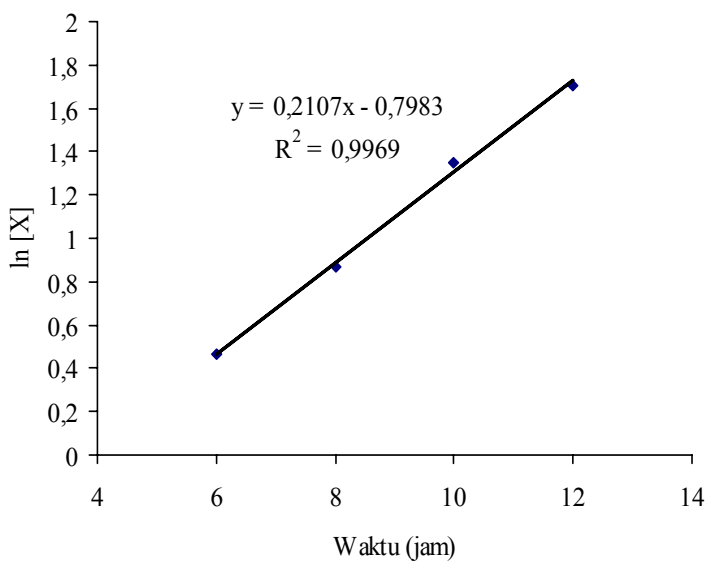

Gambar 6. Aluran waktu pertumbuhan terhadap ln [X] selama fase eksponensial

Gambar 6 menunjukkan bahwa laju pertumbuhan spesifik sel $(\mu)$ sebesar $0,21 \mathrm{jam}^{-1}$, artinya setiap jam massa sel akan meningkat dengan faktor 0,21 selama fase pertumbuhan eksponensial. Laju pertumbuhan spesifik beberapa Bacillus subtilis ditunjukkan dalam Tabel 4.

Tabel 4. Laju pertumbuhan spesifik beberapa galur Bacillus subtilis

\begin{tabular}{lcl} 
Galur & $\begin{array}{c}\text { Laju pertumbuhan } \\
\text { spesifik, } \mu,\left(\mathrm{Jam}^{-1}\right)\end{array}$ & \multicolumn{1}{c}{ Pustaka } \\
\hline M10 & 0,21 & Artikel ini \\
MUV4 & 0,14 & $\begin{array}{l}\text { Suwansukho dkk., } \\
\text { (2008) }\end{array}$ \\
BAC4 & 0,23 & Supartono, (2003) \\
\hline
\end{tabular}

Tabel 4 menunjukkan bahwa laju pertumbuhan spesifik sel Bacillus subtilis galur M10 lebih besar dari galur MUV4, namun lebih kecil dari galur BAC4. Perbedaan laju pertumbuhan spesifik ini disebabkan oleh perbedaan kondisi fermentasi, meliputi komposisi media, suhu, $\mathrm{pH}$, dan aerasi.

\section{KESIMPULAN}

Dari hasil-hasil penelitian yang diperoleh dan pembahasan di muka, dapat disimpulkan bahwa volume larutan akridin oranye 1 g. $\mathrm{L}^{-1}$ yang dapat digunakan untuk melakukan mutasi sel Bacillus subtilis BAC4 galur lokal baru adalah $10 \mu \mathrm{L}$. Bacillus subtilis M10 merupakan sel mutan dari sel Bacillus subtilis BAC4 galur lokal pada mutasi dengan larutan akridin 1 g. $\mathrm{L}^{-1}$ sebesar $10 \mu \mathrm{L}$. Komposisi media produksi yang cocok bagi produksi antibiotika oleh sel mutan Bacillus subtilis M10 adalah media yang setiap liternya mengandung: sorbitol $10 \mathrm{~g}$, bakto pepton 10 $\mathrm{g}$, urea $1 \mathrm{~g}$ dan kalsium klorida dihidrat $5 \mathrm{~g}$. Produksi antibiotika oleh sel mutan Bacillus subtilis M10 mencapai optimum setelah pertumbuhan selnya memasuki jam ke 14 setelah inokulasi.

\section{UCAPAN TERIMA KASIH}

Penelitian ini didanai oleh DP2M melalui Hibah-Bersaing tahun 2006-2007. Untuk itu melalui kesempatan ini, peneliti menyampaikan terima kasih kepada Direktur DP2M, Dirjen DIKTI Depdiknas RI.

\section{DAFTAR PUSTAKA}

Azevedo, E. C., Rios, E. M., Fukushima, K., and G. Takaki, M.C., (1993), Bacitracin Production by a New Strain of Bacillus subtilis, App. Biochem. and Biotechnol., 42, pp. 1-7.

Bell, R.G., (1991), Separation and Isolation of the isomers of bacitracin by high-performance liquid chromatography and their relationship to microbial activity, J. Pharm. \& Biomed. Anal., 9, pp. 843-847.

Bernal, G., Illanes, A., and Ciampi, L., (2002), Isolation and partial purification of a metabolite from a mutant strain of Bacillus sp. with antibiotic activity against plant pathogenic agents, EJB Electr. $J$. Biotechnol., 5, pp. 12-20.

Brock, T.D. and Madigan, M.T., (1991), Biology of Microorganisms, Sixth edition, Prentice-Hall International, Inc., London, pp. 342-369.

Butcher, R.A., Schroeder, F.C., Fischbach, M.A., Straight, P.D., Kolter, R., Walsh, C. T., and Clardy, J., (2007), The identification of bacillaene, the product of the PksX megacomplex in Bacillus subtilis, PNAS, 104, pp. 1506-1509.

Chong, Y, Yi, K.N., and Lee, S.Y., (1978), Biochemical Characteristics and Antibiotic Susceptibilities of Serratia marcescens Isolated from Clinical Specimens, Yonsei Med. J., 19, pp. 32-38.

Critchley, I.A., Draghi, D.C., Sahm, D.F., Thornsberry, C., Jones, M.E., and Karlowsky, J.A., (2003), Activity of daptomycin against susceotible and multidrug-resistant Gram-positive pathogens collected in the SECURE study (Europe) during 20002001, J. Antimicrob. Chemotherap., 51, pp. 639-649.

Crueger, W. and Crueger, A., (1984), Biotechnology: A Tectbook of Industrial Microbiology, Sinauer Associates, Inc., Sunderland-USA, pp. 15-19.

Gezer, K., Duru, M.E., Kivrak, I., Turkoglu, A., Mercan, N., Turkoglu, H., and Gulcan, S., (2006), Free-radical scavenging capacity and antibmicrobial activity of wild edible mushroom from Turkey, Af. $J$. Biotechnol., 5, pp. 1924-1928.

Griffith, D.C., Harford, L., Williams, R., Lee, V.J., and Dudley, M.N., (2003), In vivo antibacterial 
activity of RWJ-54428, a new cephalosporin with activity against Gram-positive bacteria, Antimicrob. Agents \& Chemotherap., 47, pp. 43-47.

Johnson, A.P., Warner, M., Carter, M., and Livermore, D.M., (2002), In vitro activity of CephalosporinnRWJ-54428 (MC-02479) against multidrug-resistant Gram-positive cocci, Antimicrob. Agents \& Chemotherap., 46, pp. 321-326.

Karthikumar, S., Vigneswari, K., and Jegatheesan, K., (2007), Screening of antibacterial and antioxidant activities of leaves of Eclipta prostrate (L), Scient. Res. \& Essay, 2, pp. 101-104.

Kim, K.S., Kim, T.U., Kim, I.J., Byun S.M., and Shin, Y.C., (1995), Characterization of a Metalloprotease Inhibitor Protein (SmaPI) of Serratia marcescen, App. Environ. Microbiol., 61, pp. 3035-3041.

Kusumaningrum, H.P., (1999), Determinasi spesies Bacillus sp. BAC 4 secara mikrobiologis dan molekuler, Tesis Magister, Program Pascasarjana ITB Bandung.

Lowenberger, C., Charlet, M., Vizioli, J., Kamal, S., Richman, A., Christensen, B.M., and Bullet, P., (1999), Antimicrobial Activity Spectrum, cDNA Cloning, and mRNA Expression of a Newly Isolated Member of the Cecropin Family from the Mosquito Aedes aegypti, J. Biol. Chem., 274, pp. 20092-20097.

Lugardon, K., Raffner, R., Goumon, Y., Corti, A., Delmas, A., Bulet, P., Aunis, D., and Boutique, M.H.M., (2000), Antibacterial and Antifungal Activities of Vasostatin-1, the N-terminal Fragment of Chromagranin A, J. Biol. Chem., 275, pp. $10745-$ 10753.

Meevootisom, V., Somsuk, P., Prachartam, R., and Feegel, L.W., (1983), Simple screening method for isolation of penicillin acylase producing bacteria, Environ. Microb., 46, pp. 1227-1229.

Milner, J.L., Silo-Suh, L., Lee, J.C., He, H., Clardy J., and Handelsman, J., (1996), Production of Kanosamine by Bacillus cereus UW85, App. Environ. Microbiol., 62, pp. 3061-3065.

Moeis, R.M., Ratnaningsih, E., Susanto, A.H., dan Liang, O.B., (2000), A New Bacillus strain producing penicillin acylase, Prosiding Seminar Kimia Bersama ITB-UKM Ke empat (The forth ITB-UKM Joint Seminar on Chemistry), di Yogyakarta, pp. 75-81.

Navarro, P.G., Osso, B.Q., Ortiz, R.G., Parras, P.J.M.d.l., Puentedura, M.I.M., and Gonzalez, M.C.C., (2004), Inhibition of $\beta$-lactamase II of Bacillus cereus by penamaldic derivatives of penicillins, Antimicrob. Agents \& Chemotherap., 48, pp. 1058-1060.

Petersen, P.J., Bradford, P.A., Weiss, W.J., Murphy, T.M., Sum, P.E., and Projan, S.J., (2002), In vitro and in vivo activities of Tigecycline (GAR-936),
Daptomycin, and comparative antimicrobial agents against glycopeptide-intermediate Staphylococcus aureus and other resistant Gram positif pathogens, Antimicrob. Agents \& Chemotherap., 46, pp. 25952601.

Phillips, I., (1999), The use of bacitracin as a growth promoter in animals produces no risk to human health, J. Antimicrob. Chemotherap., 44, pp. 725-728.

Supartono, (2003), Produksi dan Karakterisasi Penisilin G Asilase dan Protease Ekstrasel oleh Bacillus subtilis BAC4, Disertasi, Program Pascasarjana ITB Bandung.

Supartono, Wijayati, N., Herlina, L., dan Ratnaningsih, E., (2006), Produksi dan Karakterisasi Antibiotika dari Bacillus subtilis BAC4 Galur Lokal Baru, Laporan Penelitian Hibah Bersaing, DP2M Dirjen Dikti Depdiknas RI.

Supartono, Wijayati, N., Herlina, L., dan Ratnaningsih, E., (2008a), Mutation on Baillus subtilis BAC4 using acridine orange as an effort for increasing antibiotic production, Ind. J. Chem., 8, pp. 258-263.

Supartono, Ratnaningsih, E., Achmad, S., dan Liang, O.B., (2008b), Characterization of Extracellular Peniciln G Acylase Produced by A New Local Strain of Bacillus subtilis BAC4, HAYATI J. Bios., 15, pp. 71-76.

Suwansukho, P., Rukachisirikul, V., Kawai, F., and Kittikun, A.H, (2008), Production and applications of biosurfactant from Bacillus subtilis MUV4, Songklanakarin Journal of Science and Technology, 30, pp. 87-93.

Swenson, J.M. and Tenover, F.C., (2002), In vitro activity of a new cephalosporin, RWJ-54428, against streptococci, enterococci and staphylococci, including glycopeptide-intermediate Staphylococcus aureus, J. Antimicrob. Chemotherap., 49, pp. 845-850.

Tamehiro, N., Hosoya, Y.O., Okamoto, S., Ubukata, M., Hamada, M., Naganawa, H., and Ochi, K., (2002), Bacilysocin, a new phospholipid antibiotic produced by Bacillus subtilis 168, Antimicrob. Agents \& Chemotherap., 46, pp. 315-320.

Tsuji, M., Takema, M., Miwa, H., Shimada, J., and Kuwahara, S., (2003), In vivo antibacterial activity of S-3578, a new broad-spectrum cephalosporin: Mehicillin-Resistant Staphylococcus aureus and Pseudomonas aeruginosa experimental infection models, Antimicrob. Agents \& Chemotherap., 47, pp. 2507-2512.

Tsukiyama, R.I., Katsura, H., Tokuriki, N., and Kobayashi, M., (2002), Antibacterial Activity of Licochalcone A against Spore-Forming Bacteria, Antimicrob. Agents \& Chemotherap., 46, pp. 12261230. 
Ueda, Y. and Sunagawa, M., (2003), In vitro and in vivo activities of novel 2-(Thiazol-2-ylthio)-1 $\beta$ methylcarbapenems with potent activities against multiresistant Gram-positive bacteria, Antimicrob. Agents \& Chemotherap., 47, pp. 2471-2480.

Vila, M.M.D.C., Oliveira, R.M.D., and Gonçalves, M.M., and Tubino, M., (2007), Analytical methods for vancomycin determination in biological fluids and in pharmaceuticals, Quim. Nova, 30, pp. 395-399.

Whistler, C.A., Stockwell, V.O., and Loper, J.E., (2000), Lon Protease Influences Antibiotic Production and UV Tolerance of Pseudomonas fluorescens Pf-5, App. Environ. Microbiol., 66, pp. 2718-2725. 